\title{
Use of AWRA-R model to improve the National Water Account
}

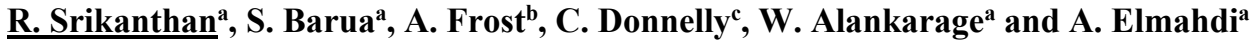 \\ ${ }^{a}$ Bureau of Meteorology, 700 Collins Street, Melbourne, Australia \\ ${ }^{b}$ Bureau of Meteorology, 300 Elizabeth Street, Sydney, Australia \\ ${ }^{c}$ Bureau of Meteorology, 69 Ann Street, Brisbane, Australia \\ Email: sri.srikanthan@bom.gov.au
}

\begin{abstract}
The National Water Account (NWA: see http:/www.bom.gov.au/water/nwa) is a federally mandated report published annually by the Bureau of Meteorology through the Commonwealth Water Act 2007. The NWA is Australia's most comprehensive water information report. The NWA discloses information about water stores and flows, water rights and water use. It also reports on the volumes of water traded and provided for economic, social, cultural and environmental benefit. It provides a picture of water resources management for the previous financial year for ten nationally significant water regions: Adelaide, Burdekin, Canberra, Daly, Melbourne, Murray-Darling Basin (MDB), Ord, Perth, South East Queensland (SEQ) and Sydney. These regions are home to about $75 \%$ of Australia's population and represent $70-80 \%$ of Australia's water use.
\end{abstract}

The NWA relies on close collaboration with many government agencies and water service providers in Australia for its information about water rights, water store volumes, flows and water use. This information is compiled based on the available observed data or estimated/modelled data where observed data is not available. The NWA relies for some of its modelled data on the Australian Water Resources Assessment River (AWRA-R) model. AWRA-R model was developed by CSIRO and the Bureau of Meteorology towards retrospective quantification of surface water items in the NWA and for water resource assessment purposes; using available observed data and inferring other water balance items that are not available. AWRA-R estimates a number of river fluxes and water store volumes such as river volume, river losses, rainfall in and evaporation from the river, water use, and overbank flooding. This paper assesses the improvement in reporting items required for the NWA through the introduction of AWRA-R; in particular assessing the reduction in the unaccounted for difference item. Relatively high unaccounted-for difference was experienced in the past as several reporting items (now estimated through AWRA-R) were partially estimated or not estimated at all.

AWRA-R is a node-link network model developed with explicit representation of key hydrological processes and anthropogenic water uses to quantify various river fluxes and stores at a daily temporal resolution along the river network. The river system is generally conceptualised as nodes at stream gauging stations and connected by river reaches. Runoff from gauged or ungauged tributaries or local contributing area between the two nodes is fed into the connecting reach as an inflow. The river reach is then used to transfer flow between two nodes with routing and transformation of the flow, precipitation and evaporation on/from the river surface, seepage losses, overbank flow, diversion and storage in reservoirs.

At present, the AWRA-R model has been applied for five NWA regions, namely, MDB, SEQ, Melbourne, Perth and Canberra. Outputs from these model applications can be used to produce the relevant reporting items on river fluxes and water store volumes which were not available or partially available in the NWA for past years (i.e. NWA 2011 - 2016). We demonstrate how including relevant reporting items estimated using AWRA-R for past years can reduce the unaccounted for difference and thus improve the NWA. It was found that the use of AWRA-R river fluxes and water store volumes in the NWA contributes considerable improvements across all five regions.

Keywords: $\quad$ River modelling, National Water Account, AWRA-R 


\section{INTRODUCTION}

The Bureau of Meteorology publishes two main Water Information Services products that are federally mandated through the Commonwealth Water Act 2007 to assess recent water resource availability and water use across Australia. These are various water resource assessment reports including Water in Australia (WIA: see http://www.bom.gov.au/water/waterassessments) report and the National Water Account (NWA: http://www.bom.gov.au/water/nwa). The two products provide users with insights to the state of Australia's water resources on an annual basis (July - June of the previous year). The WIA is a regular annual high level report on the availability and use of the nation's water resources and describes the state of the nation's water resources at a point in time and in the context of the long-term record. The NWA is Australia's most comprehensive water accounting report and covers ten major water resource regions across Australia.

The National Water Account (NWA) is a Bureau of Meteorology's Water Information Services product that has been annually published at a national and regional level since 2010 and is readily accessible by the public. The NWA relies on close collaboration with many government agencies and water service providers in Australia, and discloses information including water availability, entitlements, water allocation and water use. This information is compiled based on the available observed data and estimated data where observed data is not available. However, a number of river fluxes such as river volume, losses, rainfall and evaporation could not be reported due to lack of suitable quantification approach which leads to some unaccounted for difference.

The Australian Water Resources Assessment (AWRA) modelling system has been developed and tested under the Water Information Research and Development Alliance (WIRADA) collaboration between CSIRO and the Bureau. The AWRA modelling system has two components; AWRA-L (landscape) and AWRA-R (river) to estimate the landscape and river water balance components respectively (Hafeez et al., 2015). The AWRA-L model is a daily grid-based biophysical model of the water balance between the atmosphere, soil, groundwater and surface water stores (Viney et al., 2015, Frost et al, 2016). AWRA-L has been used in producing landscape water balance fluxes for the NWA and WIA report since 2010; and underpins the daily updated Australian Landscape Water Balance website (see www.bom.gov.au/water/landscape) providing national 5 x $5 \mathrm{~km}$ gridded estimates of soil moisture, runoff, evapotranspiration, and deep drainage from 1911 until yesterday. It should be noted that AWRA-L model has improved over the years and as a result different versions of the model were used in the past NWA. The recently developed AWRA-R model is a regulated river system model that uses a node link flow network to accumulate catchment runoff from AWRA-L, route streamflow, incorporate river rainfall, evaporation, losses, reservoirs, and simulate overbank flooding and irrigation (Dutta et al., 2017). The AWRA-R model was initially applied to the MDB with 485 reaches for research and development (Dutta et al. 2017). As part of the AWRA-R rollout across the NWA regions, the model has now been applied for four more NWA regions, namely, South East Queensland (SEQ), Melbourne, Perth and Canberra.

This paper describes the application of AWRA-R model for the five NWA regions and estimation of river fluxes and relevant water store volumes, which were not used in the past years NWA. The reduction in unaccounted for difference seen in NWA due to the inclusion of these fluxes is also presented in this paper.

\section{NWA REGIONS}

Five NWA regions, namely, MDB, SEQ, Melbourne, Perth and Canberra are used in this study. The MDB region is the catchment of the Darling River $(2,740 \mathrm{~km})$ beginning in the northern New South Wales and Murray River $(2,520 \mathrm{~km})$ including their tributaries and is located in the south east of Australia. The MDB is the largest river basin discharging to the sea in Australia, covering one seventh of the mainland and falling within Queensland, New South Wales, Victoria, South Australia and the Australian Capital Territory. There is a population of over 2 million within the basin, and irrigated agriculture is a major industry. Sustainable water management within the catchment is of high importance to sustain the industry, cultural and environmental values of the basin. The MDB has been divided into 19 catchments for managing surface water resources as shown in Figure 1. Long term average rainfall (1900-2014) is $470 \mathrm{~mm}$ but this varies widely from the northern part to the southern part of the basin. Annual rainfall ranges from more than 1,200$1,800 \mathrm{~mm}$ across the southern areas of the region to less than $300 \mathrm{~mm}$ in the west and long term average actual evapotranspiration is $433 \mathrm{~mm}$.

The South East Queensland (SEQ) region is located on the southeast coast of Queensland (Figure 2) bounded by the New South Wales-Queensland State border in the south, the Pacific Ocean in the east, the Great Dividing Range in the west, and the headwaters of the Brisbane River in the north. The SEQ region covered 
in this study consists of three water resource plan areas: Gold Coast, Logan Basin and Moreton. The area of the SEQ region is $21,331 \mathrm{~km}^{2}$ and is the most densely populated area of Queensland. The population is about

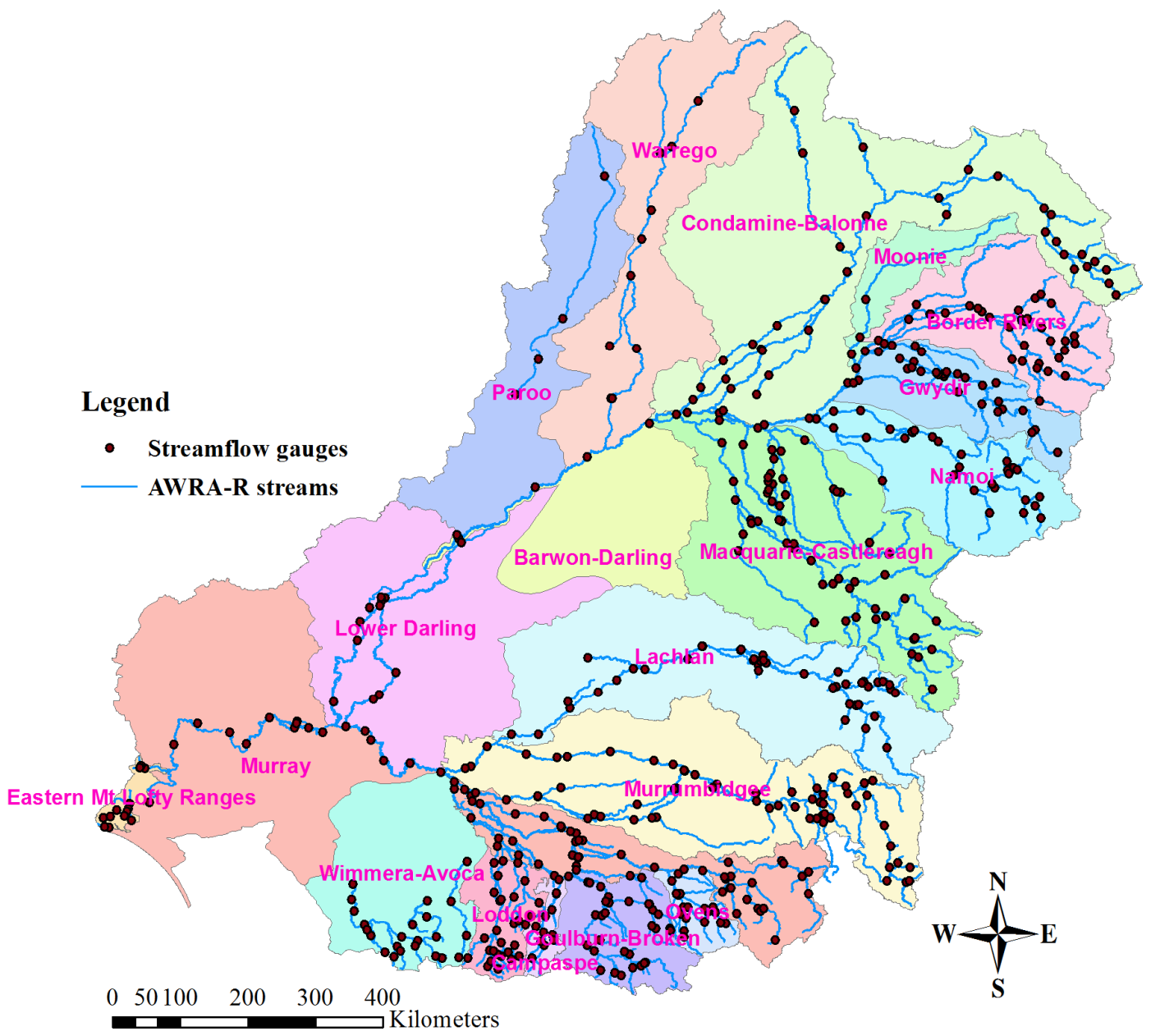

Figure 1. Node-link network for MDB

3.2 million (Australian Bureau of Statistics, 2014). Long term average rainfall (1900-2014) is $971 \mathrm{~mm}$ and long term average actual evapotranspiration is $847 \mathrm{~mm}$.

The Melbourne region (Figure 3) extends from the coastlines of Port Phillip Bay, Western Port Bay, and Bass Strait to the south, the Yarra Ranges in the east and the Great Dividing Range to the north and west. It consists of the Bunyip, Yarra, Maribyrnong and Werribee river catchments. The population is about 4.53 million (Australian Bureau of Statistics, 2014). Long term average rainfall (1900-2016) is $862 \mathrm{~mm}$ and long term average actual evapotranspiration is $697 \mathrm{~mm}$.

The Perth region (Figure 4) includes the Swan-Canning river system, the Murray River (Perth-Murray) and Harvey River catchments, two groundwater management areas, and two irrigation districts within the Harvey Water Irrigation Area. The population is about 1.9 million (Australian Bureau of Statistics, 2014). Long term average rainfall (1900-2016) is $797 \mathrm{~mm}$ and long term average actual evapotranspiration is $632 \mathrm{~mm}$.

The NWA Canberra region (Figure 5) is located in the southeast of Australia and within the MDB. It is home to approximately 426,000 people and covers an area of 4,202 $\mathrm{km}^{2}$ (Australian Bureau of Statistics, 2014). The region is characterized by forested mountains in the south and west of the region and plains in the north. The Murrumbidgee River is the main waterway running through the region and its tributaries within the NWA Canberra region include the Cotter, Gudgenby, Molonglo and Queanbeyan Rivers. The long-term average rainfall within the region is about $794 \mathrm{~mm}$ (period 1900-2014) and long term average actual evapotranspiration is $658 \mathrm{~mm}$. In terms of water resources management, the NWA Canberra region has significant importance to the city of Canberra, the largest urban centre within the MDB. 


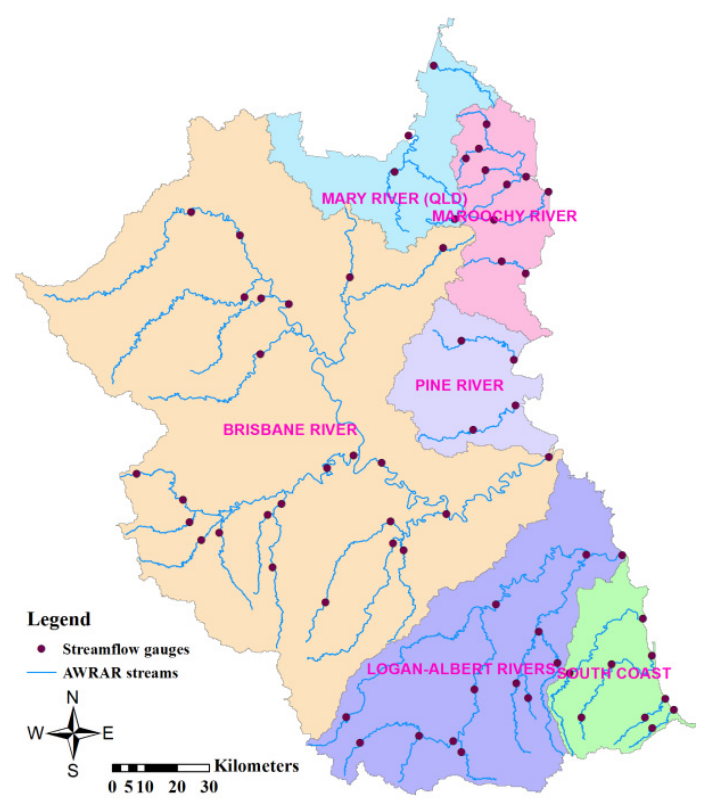

Figure 2. Node-link network for SEQ

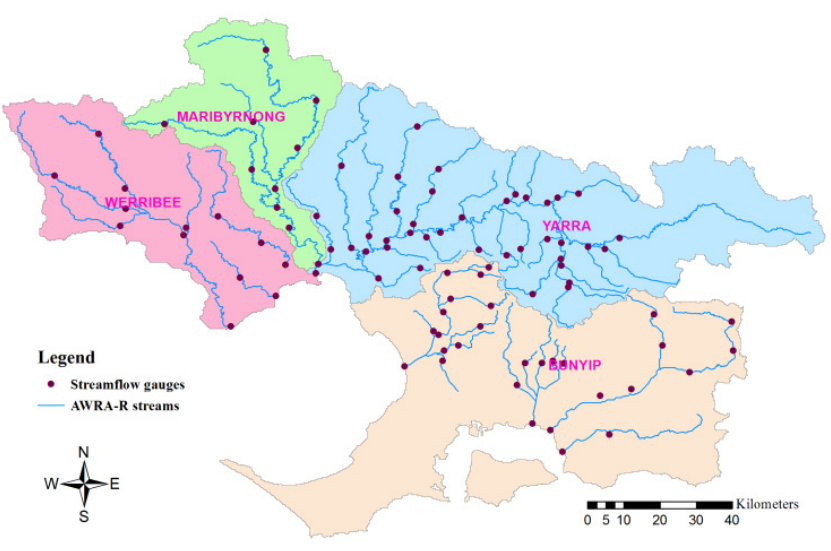

Figure 4. Node-link network for Perth

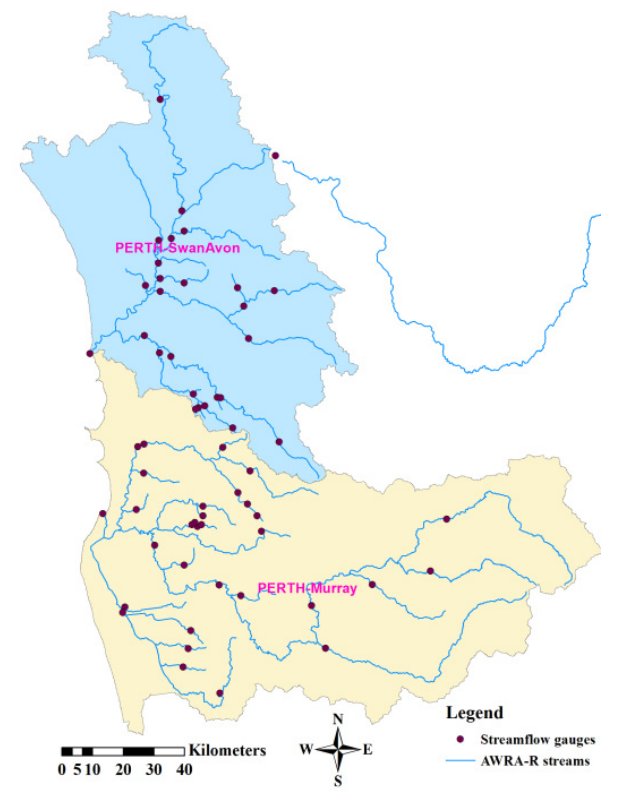

Figure 3. Node-link network for Melbourne

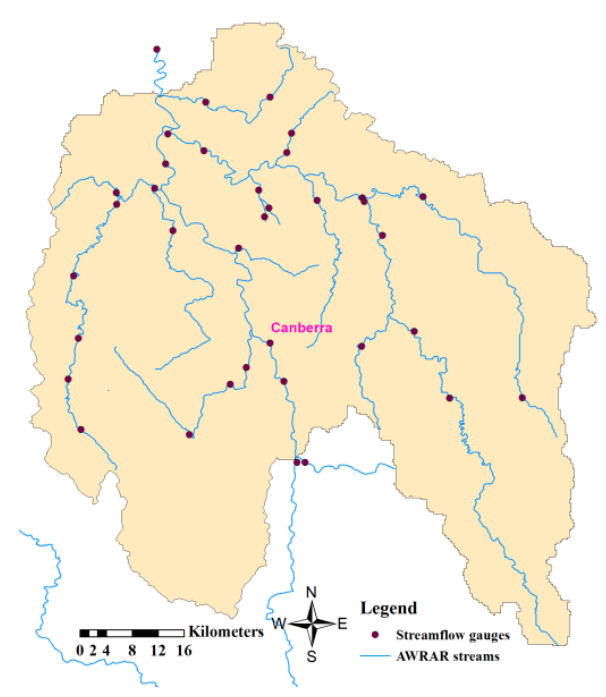

Figure 5. Node-link network for Canberra

\section{AWRA-R MODEL}

AWRA-R is a node-link network model for modelling the river system in a region. The nodes are selected at stream gauging stations and connected by river reaches. The river network starts and ends with a node and there are two types of reaches: headwater and residual (or the non-headwater) reaches. To build an AWRA-R model, a catchment is sub-divided into a number of sub-catchments based on the node-link river network. AWRA-R model has evolved over the last couple of years to include new components such as overbank flooding and irrigation and to improve some of the existing components such as headwater reaches. A conceptual diagram of AWRA-R model for a residual reach is shown in Figure 6. The general form of the water balance equation used in the model is given by

$$
\widehat{Q_{d} / s}=\left(Q_{u} / s\right)_{\text {rout }}+Q_{r}+Q_{s}-Q_{d}+Q_{i r r}-Q_{u}-Q_{s d}+Q_{p}-Q_{e}-Q_{a}-Q_{f p}+Q_{f p r}-Q_{g w}
$$

where $\widehat{Q_{d / s}}$ is the simulated flow at the downstream gauge $\left(\mathrm{m}^{3} / \mathrm{sec}\right), Q_{u / s}$ the concurrent flow at the upstream gauges (including gauged tributaries) $\left(\mathrm{m}^{3} / \mathrm{sec}\right),\left(Q_{u / s}\right)$ rout the upstream inflow following routing $\left(\mathrm{m}^{3} / \mathrm{sec}\right)$, $Q_{r}$ the runoff generated from the local ungauged catchment $\left(\mathrm{m}^{3} / \mathrm{sec}\right), Q_{s}$ the contribution from any storages $\left(\mathrm{m}^{3} / \mathrm{sec}\right), Q_{d}$ the loss due to irrigation diversion $\left(\mathrm{m}^{3} / \mathrm{sec}\right), Q_{i r r}$ the total return flow from irrigated area 
$\left(\mathrm{m}^{3} / \mathrm{sec}\right), Q_{u}$ the net loss due to urban diversion $\left(\mathrm{m}^{3} / \mathrm{sec}\right), Q_{s d}$ the rural water use (other than irrigation) for stock and domestic ( $\left.\mathrm{m}^{3} / \mathrm{sec}\right), Q_{p}$ the flux to the river store due to rainfall $\left(\mathrm{m}^{3} / \mathrm{sec}\right), Q_{e}$ the flux from the river due to evaporation $\left(\mathrm{m}^{3} / \mathrm{sec}\right), Q_{a}$ the flow diverted to anabranches $\left(\mathrm{m}^{3} / \mathrm{sec}\right), Q_{f p}$ the overbank flow to floodplain $\left(\mathrm{m}^{3} / \mathrm{sec}\right), Q_{f p r}$ the return flow from floodplain $\left(\mathrm{m}^{3} / \mathrm{sec}\right)$ and $Q_{g w}$ the flux from river to groundwater $\left(\mathrm{m}^{3} / \mathrm{sec}\right)$.

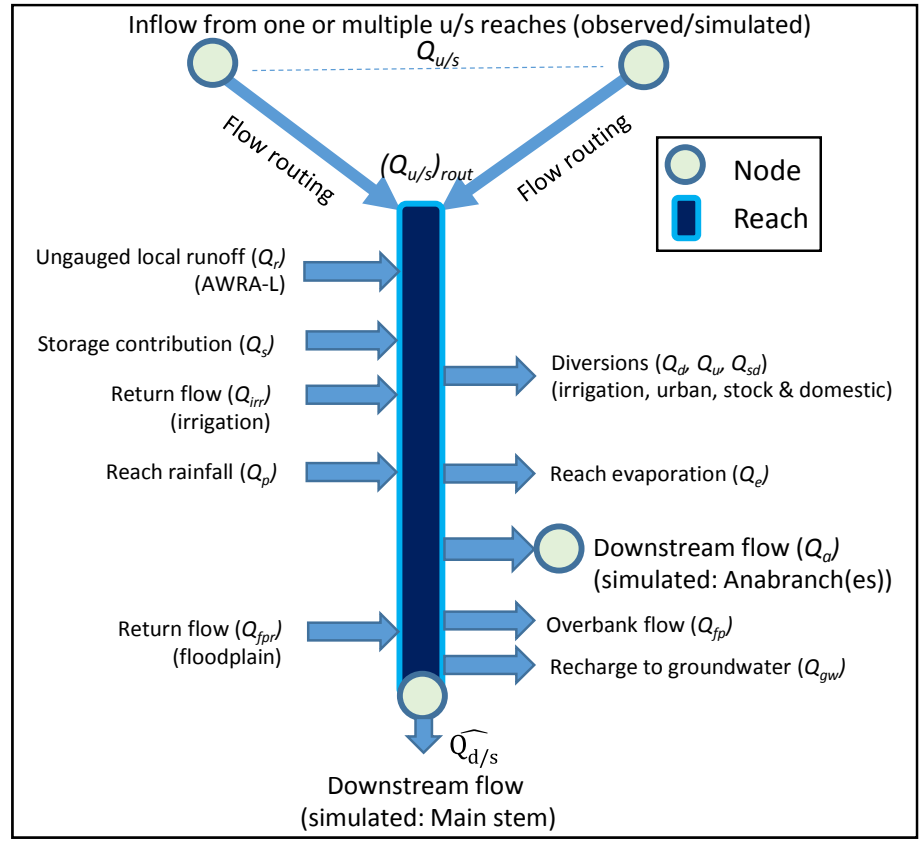

Figure 6. A conceptual diagram of the AWRA-R model (Dutta et al., 2015)

The AWRA-R model has eight parameters to calibrate: three flow routing parameters ( $\operatorname{Lag}, x$ and $K$ ), overbank threshold $(O T)$, fraction of return flows from overbank flooding $(F R)$, two infiltration loss parameters $\left(M_{1}\right.$ and $\left.M_{2}\right)$ and a scaling factor for the ungauged catchment runoff $(S F)$. Calibration is done by estimating a separate set of parameters for each reach, optimised to an objective function combining bias with the daily Nash-Sutcliffe coefficient of efficiency (NSE), using a shuffled complex evolution algorithm (Duan et al., 1992)

\section{APPLICATION OF AWRA-R MODEL TO NWA REGIONS}

To apply the AWAR-R model for the five NWA regions, all available streamflow data for the gauging stations are obtained for the period from January 1970 to June 2016. Based on the length and quality of data, gauging stations are selected to form the node-link network. The river section between two nodes is defined as a reach. The node-link network formed for the five regions are shown in Figures 1 to 5 while Table 1 presents the number of reaches in the AWRA-R model to model these regions. Other input data such as storage volume and level, river level, diversion, river cross-section (from BoM database), rainfall, runoff, Morton's shallow lake evaporation (calculated from climate data), stream length (from Geofabric product, http://www.bom.gov.au/water/geofabric) and soil characteristics (from ASRIS, Johnston et al., 2003).are also obtained.

Reach-by-reach calibration is used to optimise the eight parameters for each reach of the AWRA-R model. The objective function is a combination of bias and Nash-Sutcliff efficiency (NSE). The median relative bias, daily and monthly NSE values for the five regions are presented in Table 2. It shows that the performance vary from one region to another with the median daily and monthly NSE varying from 0.41 to 0.68 and 0.55 to 0.92 respectively while the median relative bias is close to zero. The calibrated AWRA-R model is then run to simulate the relevant fluxes required for the national water account (NWA).
Table 1. Number of reaches in AWRA-R

\begin{tabular}{|l|c|}
\hline Region & No of reaches \\
\hline MDB & 485 \\
\hline Melbourne & 92 \\
\hline SEQ & 65 \\
\hline Canberra & 36 \\
\hline Perth & 59 \\
\hline
\end{tabular}


Srikanthan et al., Use of AWRA-R model to improve the National Water Account

Table 2. Performance of the AWRA-R Model

\begin{tabular}{|l|c|c|c|c|c|}
\hline & MDB & Melbourne & SEQ & Canberra & Perth \\
\hline Median relative bias & -0.02 & -0.05 & -0.04 & -0.05 & -0.01 \\
\hline Median daily NSE & 0.56 & 0.48 & 0.68 & 0.68 & 0.41 \\
\hline Median monthly NSE & 0.76 & 0.66 & 0.92 & 0.82 & 0.55 \\
\hline
\end{tabular}

\section{RESULTS AND DISCUSSIONS}

The unaccounted for difference is calculated by using the equation

$$
\text { unaccounted for difference }=\text { closing storage }+ \text { outflows }- \text { opening storage }- \text { inflows }
$$

The unaccounted for difference volumes reported in the NWA for the last six years for all the regions except MDB are shown in light blue colour in Figure 7. The numbers presented for MDB are the volumes provided under reporting item "River and floodplain leakage, evaporation and errors". Currently this item is back calculated from the fluxes and stores so that the water balance closes. Even though the reported unaccounted for difference is reported as zero for MDB, the volume provided in the above reporting item is used in this study to investigate how much of that volume is explained by the AWRA-R model. The required fluxes and store volumes obtained from AWRA-R and the latest version of AWRA-L for the last six financial years are incorporated and the unaccounted-for differences are re-calculated. The revised unaccounted for differences are also shown in Figure 7 along with the percentage reduction in unaccounted for difference.
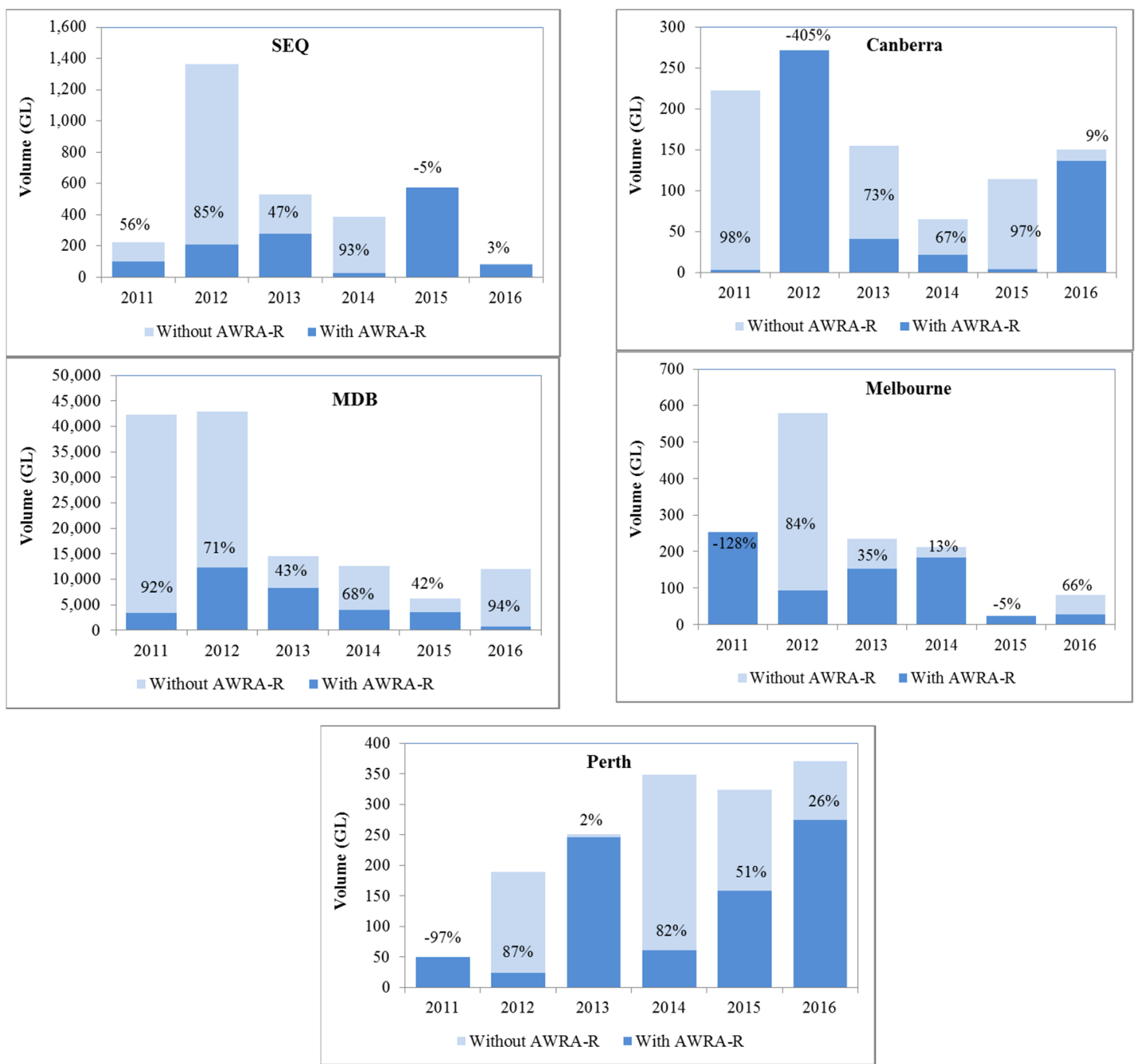

Figure 7. Unaccounted for difference with and without AWRA-R fluxes 
The reduction in the unaccounted for difference is quite considerable as shown in Figure 7 with substantial improvements in most of the accounts. However, for five cases, the inclusion of AWRA-R results made the unaccounted for difference worse $(-5 \%,-405 \%,-128 \%,-5 \%$ and $97 \%)$. Of these five, two are fairly small $(5 \%)$ while the other three $(-405 \%,-128 \%$ and $97 \%)$ are in the early years of the NWA. The reason for the unaccounted differences becoming worse in Melbourne and Perth for 2011 is the use of the earliest version of AWRA-L model for the runoff. Comparing the runoff for the year 2011 against a year with similar rainfall indicates a large discrepancy between AWRA-L model versions. The error in the runoff is counter balanced by the fluxes not included in the NWA2011 to give a smaller unaccounted for difference. The reason for the larger unaccounted for difference in the Canberra region is an apparent error in the streamflow data for March 2012. The water level and streamflow data are not consistent for the period 1 to 13 March 2102. Disregarding this error, it can be concluded that using the AWRA-R model to estimate non-observable fluxes significantly reduces the unaccounted for differences of the National Water Accounts.

\section{CONCLUSIONS}

AWRA-R model is applied to the five NWA regions to obtain the river fluxes and store volumes required in the NWA. AWRA-R application produces NWA items those were not either previously difficult to estimate or contained error. These items are incorporated in the NWA to recalculate the unaccounted for differences for the financial years 2010-11 to 2015-16. The recalculated values are then compared with the corresponding values published in the NWA. The comparison has shown that the unaccounted-for difference has decreased significantly for most the years across all the regions.

\section{ACKNOWLEDGMENTS}

The authors wish to acknowledge CSIRO for developing the AWRA-R model, reporting partners including DPI water (NSW), DELWP (VIC), DNRM (QLD), Department of Water (WA), Melbourne Water and Southern Rural Water (VIC), SEQ Water for supplying the required data, and Adam Smith, Avi Ramchurn, Alison Oke, Stuart Baron-Hay and Nathan Campbell for their assistance in rolling out AWRA-R to the NWA regions.

\section{REFERENCES}

Australian Bureau of Statistics (2014). Regional population growth, Australia 2012-13, viewed 28 January 2015, www.abs.gov.au/AUSSTATS/abs@.nsf/DetailsPage/3218.02012-13.

Bureau of Meteorology (2014). State of the climate 2014. Bureau of Meteorology, Australia.

Duan, Q. D., Sorooshian, S., Gupta, V. K. (1992). Effective and efficient global optimisation for conceptual rainfall-runoff models. Water Resources Research, 28 (4), 1015-1031.

Dutta, D., Kim, S., Hughes, J., Vaze, J., Yang, A. (2015). AWRA-R version 5.0 Technical Report, CSIRO.

Dutta, D., Vaze, J., Kim, S., Hughes, J., Yang, A., Teng, J., Lerat, J. (2017). Development and application of a large scale river system model for National Water Accounting in Australia. Journal of Hydrology, 547, 124-142.

Frost, A., Ramchurn, A. and Hafeez, M. (2016) Evaluation of the Bureau's Operational AWRA-L Model. Bureau of Meteorology Techical Report.

Hafeez, M., Frost, A., Vaze, J., Dutta, D., Smith, A., Elmahdi, A., (2015). A new integrated continental hydrological simulation system. An overview of the Australian water resource assessment modelling system (AWRAMS). Water. Journal of the Australian Water Association, 42(3) 75-82.

Johnston, R. M., Barry, S. J., Bleys, E., Bui, E. N., Moran, C. J., Simon, D. A. P., Carlile, P., McKenzie, N. J., Henderson, B. L., Chapman, G., Imhoff, M., Maschmedt, D., Howe, D., Grose, C., Schoknecht, N., Powell, B. and Grundy, M. (2003) 'ASRIS: the database', Soil Research, 41(6), pp. 1021-1036. doi: http://dx.doi.org/10.1071/SR02033

Viney N, Vaze J, Crosbie R, Wang B, Dawes W and Frost A (2015). AWRA-L version 5.0 technical description of model algorithms and inputs: AWRA-Lv5 Technical Report, CSIRO, Australia. 